\title{
Obtaining Biodiesel by Direct Transesterification of Botryococcus braunii and Coccomyxa subellipsoidea
}

\author{
Blanca Estela Chávez-Sandoval*1, Karen Fernanda Hernández-Salgado², Martha Martínez-García ${ }^{3}$, \\ Hugo Joaquín Ávila-Paredes ${ }^{4}$, Fidel Humberto Díaz-Álvarez ${ }^{5}$, Francisco García-Franco ${ }^{6}$ \\ ${ }^{1}$ Depto. de Matemáticas Aplicadas y Sistemas, Universidad Autónoma Metropolitana, Av. Vasco de Quiroga \\ No. 4871, Santa Fe, Cuajimalpa de Morelos, C.P. 05348, Ciudad de México, México. \\ ${ }^{2}$ Depto. de Energía, UAM-Azcapotzalco Av. San Pablo No. 180, Col. San Martín Xochinahuac, CP. 02200. \\ Ciudad de México, México. \\ ${ }^{3}$ Unidad de Biotecnología y Prototipos, Facultad de Estudios Superiores, Iztacala, Universidad Nacional \\ Autónoma de México (FES-I, UNAM). Av. De los Barrios No. 1 Col. Los Reyes Iztacala, Tlalnepantla de Baz, \\ Estado de México, CP. 54090. México. \\ ${ }^{4}$ Depto. de Ing. de Procesos e Hidráulica, Universidad Autónoma Metropolitana, Iztapalapa. \\ ${ }^{5}$ Facultad de Estudios Superiores, Iztacala, Universidad Nacional Autónoma de México (FES-I, UNAM). Av. \\ De los Barrios No. 1 Col. Los Reyes Iztacala, Tlalnepantla de Baz, Estado de México, CP. 54090. \\ ${ }^{6}$ Depto. de Ciencias Naturales, Universidad Autónoma Metropolitana, Av. Vasco de Quiroga No. 4871, Santa \\ Fe, Cuajimalpa de Morelos, C.P. 05348, Ciudad de México, México.
}

*Corresponding author: Blanca Estela Chávez-Sandoval, email: blanchavez29@gmail.com, Telephone: +52 (55) 5814 6525, Cell. Phone: +52 5548101589.

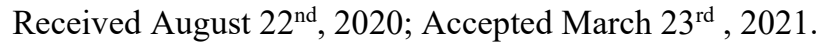

\section{DOI: http://dx.doi.org/10.29356/jmcs.v65i3.1430}

\begin{abstract}
Biofuels have been obtained from vegetable oils, animal fats and recently from microorganisms such as algae, bacteria or yeasts that present a significant content of triacylglycerols through a transesterification reaction. Technical problems with biodiesel or agrodiesel (Term recently used, in this work we will use biodiesel), include oxidative stability, cold flow, and increased NOx emissions. The solution to these problems involves the use of additives on the one hand or modifying the fatty acid composition of the microorganisms alternatively, either through changes in the cultivation temperature, addition of nanomaterials, or through genetic modification, to obtain high-quality biofuels. In this work, two species of microalgae with high fatty acid content were obtained, Botryococcus braunii originating from Cuzco, Peru and Coccomyxa subellipsoidea C-169, from Marble Point, Antarctica, both were cultivated under optimal conditions and later direct transesterification was performed to obtaining biodiesel. The main objective was to develop an economical and viable process that allows it to compete with fossil fuels, based on obtaining biomass and the transesterification method. Here, direct transesterification was effective and allows to significantly reduce the problems associated with the increase in costs of obtaining biodiesel, because reduces critical steps, also the biodiesel thus obtained represents an advance in the development of high-quality biofuels, large-scale and inexpensive.
\end{abstract}

Keywords: Biodiesel, direct transesterification, microalgae, B. braunii, C. subellipsoidea C-169.

Resumen. Los biocombustibles se han obtenido desde finales del siglo XIX a partir de aceites vegetales, grasas animales y recientemente a partir de microorganismos como algas, bacterias o levaduras que presentan un contenido significativo en triacilgliceroles mediante una reacción de transesterificación. Algunos de los 
problemas técnicos con el biodiésel o agrodiesel (término usado recientemente, en este trabajo usaremos biodiesel) son: estabilidad oxidativa, flujo en frío y aumento de emisiones de NOx. La solución a estos problemas incluye el uso de aditivos, por un lado, o modificar la composición de ácidos grasos de los microorganismos por otro, ya sea mediante cambios en la temperatura de cultivo, adición de nanomateriales, o mediante modificación genética, para obtener biocombustibles de alta calidad. En este trabajo se utilizaron dos especies de microalgas con gran contenido en ácidos grasos, Botryococcus braunii originaria de Cuzco, Perú y Coccomyxa subellipsoidea C-169, de Punta Mármol, Antártida, ambas fueron cultivadas en óptimas condiciones y posteriormente se realizó la transesterificación directa para obtener el biodiésel. El principal objetivo fue desarrollar un proceso económico y viable, que permita competir con los combustibles fósiles, a partir de la obtención de biomasa y el proceso de transesterificación. La transesterificación directa fue exitosa y permitió reducir significativamente los problemas asociados con el aumento de costos de obtención de biodiésel, ya que reduce pasos críticos del proceso, además el biodiésel así obtenido representa un avance en el desarrollo de biocombustibles de alta calidad, a gran escala y de bajo costo.

Palabras clave: Biodiésel, Transesterificación directa, Microalgas, B. braunii, C. subellipsoidea C-169.

\section{Introduction}

Energy is one of the most important factors for economic and industrial growth, and there are two major problems to be solved immediately in the energy area: the decrease in oil reserves and the pollution caused by the burning of fossil fuels. From the Industrial Revolution (XVIII and XIX century) began to be contaminated by gases emitted during production processes, and until the twentieth century, scientists and politicians began to consider the generated alterations to ecosystems and health [1]. The oil crisis of 1970 sparked worldwide interest in the development of biofuels as an alternative source to the use of fossil fuels. From this, the need arose for effective options to replace petroleum-based fuels with renewable, clean, and sustainable [2]; Biodiesel is environmentally friendly, renewable, nontoxic, biodegradable, thus plays a significant role in meeting the energy demands [3].

The use of high oil content crops derived from corn, soybean, canola, palm oil, among others have been studied and used to obtain bioethanol or biodiesel [4,5], however, these crops require large tracts of land to provide significant amounts of biomass for the fuel production, this has caused food crisis due to the scarcity of cultivable soils, therefore using microorganisms such as microalgae are an excellent raw material to produce biofuels [6].

Concerning biofuel prices, international crude oil costs are expected to double at least until 2026, which will reduce the demand for gasoline and diesel fuels in developed countries, while the demand for biofuels in that same period, should keep continuous in developing countries, and the ascendent trend in biofuel prices will also it would reflect the evolution of the prices of the main raw materials to produce biodiesel and ethanol (Fig. 1) [7].

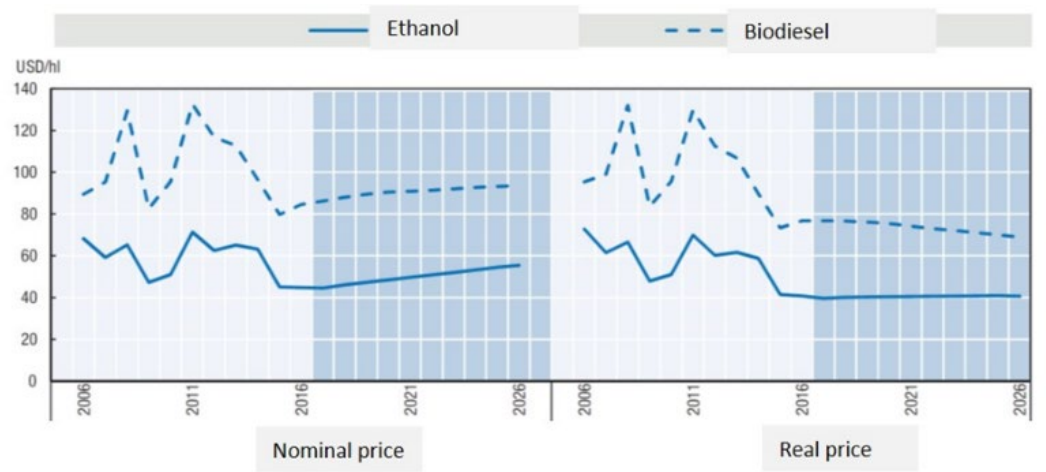

Fig. 1. Increasing trend in biofuel prices. 
Currently, we have studies that evaluate the cellular and molecular bases of lipid bodies and their accumulation in lipids through the metabolic synthesis of hydrocarbons. The studies carried out have revealed the main advantages and disadvantages of the use of microalgae as energy sources $[8,9,10,11]$. However, it is important to identify the biochemical and environmental factors that could accelerate the synthesis and promote the accumulation of hydrocarbons and the obtaining of high-quality biodiesel from microalgae, bacteria, and yeasts, among other microorganisms, cultivated or not in wastewater [12, 13, 14]. The metabolic pathways involved in the biosynthesis of energy-rich compounds, such as lipids and carbohydrates in microalgae, are directly influenced by environmental factors [15]. Furthermore, these microorganisms have lipid composition patterns according to their genome, geographic location or a combination of both factors and are currently considered adequate raw materials for biofuel production due to the global environmental emergency.

Regarding transesterification, there are several approaches to improve the properties of the biodiesel obtained, use other light alcohols instead of methanol, use methyl palmitoleate and esters of decanoic acid, in addition to methyl oleate, among others.

In this work, biodiesel was successfully obtained from two species of microalgae with high lipid content grown in domestic wastewater, by direct transesterification; This methodology makes it possible to reduce steps in obtaining biofuel and therefore costs, which on a large scale can become highly relevant from the economic and energy point of view.

\section{Experimental}

\section{Materials and Methods}

Acquisition and maintenance of strains to obtain biomass.

Two species of microalgae with high oil capacity were selected. Unialgal cultures of Botryococcus braunii were used, which is a very widespread green microalgae, its optimal growth temperature is $23^{\circ} \mathrm{C}$, this species is notable for its ability to produce large amounts of hydrocarbons, especially oils in the form of triterpenes, hydrocarbons known as botryococcenes, which come to represent around 30-40\% of its dry weight, that can be used as renewable feedstocks for producing combustion engine fuels [15, 16,]. The strain was purchased from the university of Texas in the USA with the code UTEX B 2441 (Fig. 2. A), and Coccomyxa subellipsoidea C-169 (Fig. 2. (B)), is a eukaryotic unicellular green microalga of approximately 3 to $9 \mu \mathrm{m}$ in diameter, it was discovered in the Arctic circle in the 1960s, originally from Marble Point, Antarctica [17]. With an optimal temperature for growth of around $20^{\circ} \mathrm{C}$. In the last 20 years it has been used as a model organism in pioneering studies in the architecture of green algae chromosomes [18]. It contains enzymes involved in biosynthesis and lipid modification, allowing it to synthesize a greater diversity of components of the cell membrane. These enzymes and metabolic properties are of potential interest in the development of technologies for the conversion of lipids from microalgae to biodiesel or valuable fatty acids; the strain was donated from the National Autonomous University of Mexico (FES-I, UNAM).
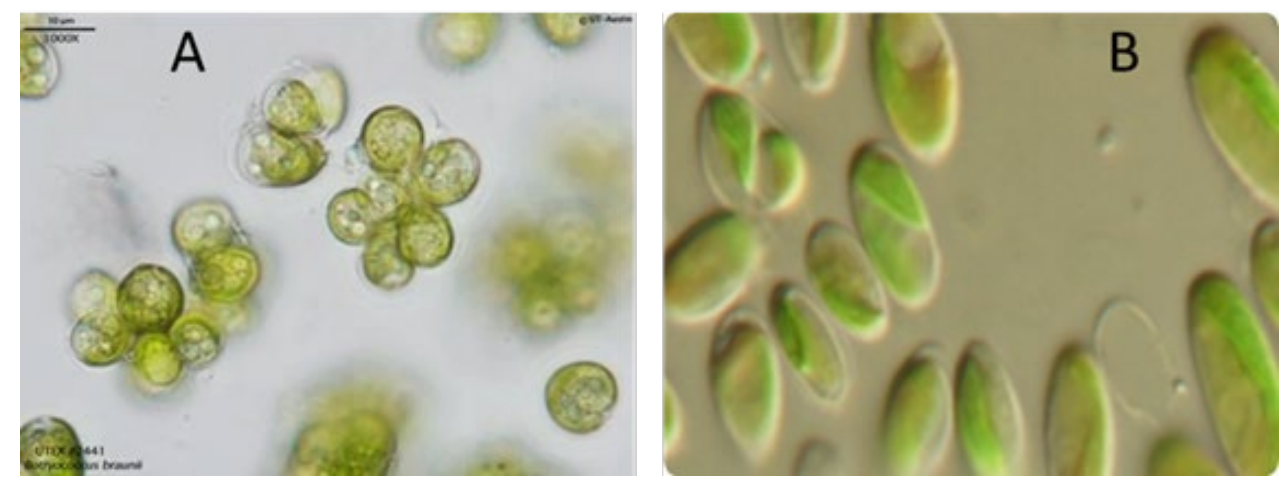

Fig. 2. (A) Botryococcus braunii UTEX 2441. (Image obtained from the UTEX culture collection). (B) Coccomixya subellipsoidea C-169 (image obtained from http://greenc.sciencedesigners.com). 
The biomass of both microalgae was cultivated separately in an autotrophic manner in domestic wastewater, obtained from the pilot plant for wastewater treatment of the UAM-Azcapotzalco, was characterized using physicochemical methods and sterilized in a vertical laboratory autoclave of soil model ATV 850; considering that comes from human feces and urine, from personal and kitchen care and house cleaning, they usually contain a large amount of organic matter and microorganisms, as well as traces of soaps, detergents, bleach and fats. Each strain was inoculated into within a closed culture system (Photobioreactors) with white light and controlled conditions of temperature $\left(23{ }^{\circ} \mathrm{C}\right.$ for $\mathrm{B}$. braunii and $20^{\circ} \mathrm{C}$ for C. subellipsoidea C-169), $\mathrm{pH}$ and a photoperiod of $12 / 12$ at $4,200 \mathrm{lux} / \mathrm{m}^{2}$.

Inoculum were started with $1 \mathrm{~mL}$ of each microalgae strain already activated and transferred into $10 \mathrm{~L}$ of residual water. $\mathrm{PH}$, temperature, optical density (OD) and nitrogen concentration (NH4 + ammonium ion) were monitored every $72 \mathrm{~h}$ at the same time.

The $\mathrm{pH}$ was monitored using a Methler Toledo potentiometer. The temperature was monitored to ensure cultures were kept at the optimum temperature using a PCE-600 infrared laser thermometer. The OD was monitored using the Perkin Elmer Lambda $35 \mathrm{UV}-\mathrm{Vis}$ spectrophotometer, at a maximum wavelength of $683.6 \mathrm{~nm}$, for $B$. braunii, to determine the growth kinetics of this microalgae. The monitoring of the metabolic assimilation of nitrogen as ammonium ion present in the aqueous medium was determined with a Vernier ${ }^{\circledR}$ brand selective ammonium ion ( $\mathrm{NH} 4+$ ) electrode.

\section{Sonication}

The biomass obtained was introduced to a Branson-1510-DTH-Ultrasonic sonicator of $40 \mathrm{KHz}$ at 300 $\mathrm{W}$, for 30 minutes, to break the cell walls of the microalgae and facilitate the obtaining of lipids $[2,19]$.

\section{Biomass drying}

Since water could generate a significant negative effect on in situ biodiesel production, the biomass obtained was dried in the following way: the culture was centrifuged using an Eppendorf model 5810R brand centrifuge, at $4000 \mathrm{rpm}$ for $4 \mathrm{~min}$ and at a temperature of $4{ }^{\circ} \mathrm{C}$, and the supernatant was removed by decantation. $90 \%$ of the humidity in the biomass was eliminated in a Shel Lab brand SMO5 model laboratory oven at 310 $\mathrm{K}$ for $12 \mathrm{~h}$. it was subsequently pulverized in a mortar.

\section{Direct transesterification with acid catalysis and co-solvent}

Direct transesterification was performed using the method of [12] with some modifications, briefly: Dry biomass reacts with sulfuric acid and methanol. Methanol acts as an extraction solvent and an esterification reagent, in addition hexane was used as an additional solvent to obtain oils easier and to improve the contact of these oils with the esterification reagent. It should be noted that the analyzes were carried out in triplicate.

A 3: 1 alcohol / oil molar ratio was used. In a Hass tube, $1 \mathrm{~g}$ of microalgae powder was added with 4 $\mathrm{mL}$ of methanol, $8 \mathrm{~mL}$ of n-hexane, $8 \mathrm{~mL}$ of $0.5 \mathrm{M} \mathrm{H} 2 \mathrm{SO} 4$ and allowed to react at $358 \mathrm{~K}$, for $180 \mathrm{~min}$, in an autoclave, model ATV 850, this reaction produced methyl ester fatty acids (FAME) and glycerin which were separated in a settling funnel for $24 \mathrm{~h}$. Later, the densest phase was removed (glycerin and algal biomass residues), thus obtaining the oily phase, which is biodiesel, this mixture was taken to a Buchi R210 rotary evaporator, to recover the hexane and finally the biodiesel obtained was washed with $3 / 4$ of distilled water $\mathrm{V}: \mathrm{V}$.

\section{Biodiesel Characterization \\ Fourier transform infrared spectroscopy (FT-IR)}

For this characterization, Infrared PerkinElmer FT-IR Spectrometer Frontier was used. $20 \mathrm{~mL}$ of biodiesel sample was used, and a scan was made in the wavelength range of $400 \mathrm{~cm}^{-1}$ to $4000 \mathrm{~cm}^{-1}$.

\section{GC-linked mass spectrometry (GC-MS)}

The FAME obtained were identified with the mass spectra of each compound, comparing them with the equipment library and the standard samples injected into the gas chromatograph equipped with a Gas Chromatograph (PerkinElmer ${ }^{\circledR}$ Clarus 580) coupled to Mass Spectrometry (PerkinElmer ${ }^{\circledR}$ Clarus SQ 8S). For the chromatographic method of detection of FAME used a furnace temperature ramp of $283 \mathrm{~K} / \mathrm{min}$, from 433 $\mathrm{K}$ to $503 \mathrm{~K}$ for $8 \mathrm{~min}$, with an injector temperature of $498 \mathrm{~K}, 1 \mathrm{~mL} / \mathrm{min}$ Helium flow and an Elite-Wax column 
of $30 \mathrm{~m}$ long and a maximum temperature of $513 \mathrm{~K}$. The proportion of methyl esters was estimated from the ratio of chromatographic areas, considering the area of each of the products between the total area of all the peaks identified as methyl ester.

\section{Results and discussion}

\section{Obtain Biomass}

Light intensity, temperature and nutrient concentration are important factors in the regulation of microalgae growth. [20] remark that the low luminous intensities $(<10,000$ lux $)$ registered inside the laboratories cause that the cellular growth of the microalgae is low, meanwhile with luminous intensities registered abroad, higher cell harvests are obtained, around 20 to $120 \mathrm{~K}$ lux. To reduce cultivation costs, natural light can be used in mass cultivation. Similarly, the temperature is of great relevance in cell growth and artificial light can influence changes in optimal temperatures, in Fig. 3(A), the behavior of temperature during the growth of microalgae is observed.

Regarding $\mathrm{pH}$, domestic wastewater usually has a $\mathrm{pH}$ close to neutral (6.5-8.0) we observed that Coccomyxa subellipsoidea $\mathrm{C} 169 \mathrm{pH}$ it was $7 \pm 0.5$, meanwhile Botryococcus braunii had a $\mathrm{pH}$ of $7.5 \pm 0.5$ this difference may be due to the variances in nutrient consumption and the metabolism of microalgae (Fig. 3. B).

Another important aspect for the profitability of the crop is the enrichment of the nutritive medium, the proposal of the application of wastewater as an alternative to conventional culture media to produce biomass in bioreactors. In terms of ammonium ion consumption, the results indicated a higher consumption in Botryococcus braunii compared to Coccomyxa subellipsoidea $\mathrm{C} 169$, the initial concentration of ammonium ion in the wastewater was $22.7 \mathrm{~g} / \mathrm{L}$ and ended with $6.9 \mathrm{~g} / \mathrm{L}$ and $13.5 \mathrm{~g} / \mathrm{L}$ respectively (Fig. 3 (C)). The consumption of ammonium ion was lower in Coccomyxa subellipsoidea C169 compared to B. braunii, this is perhaps because the cells of $C$. subellipsoidea $\mathrm{C} 169$ are smaller and grow more slowly [21].
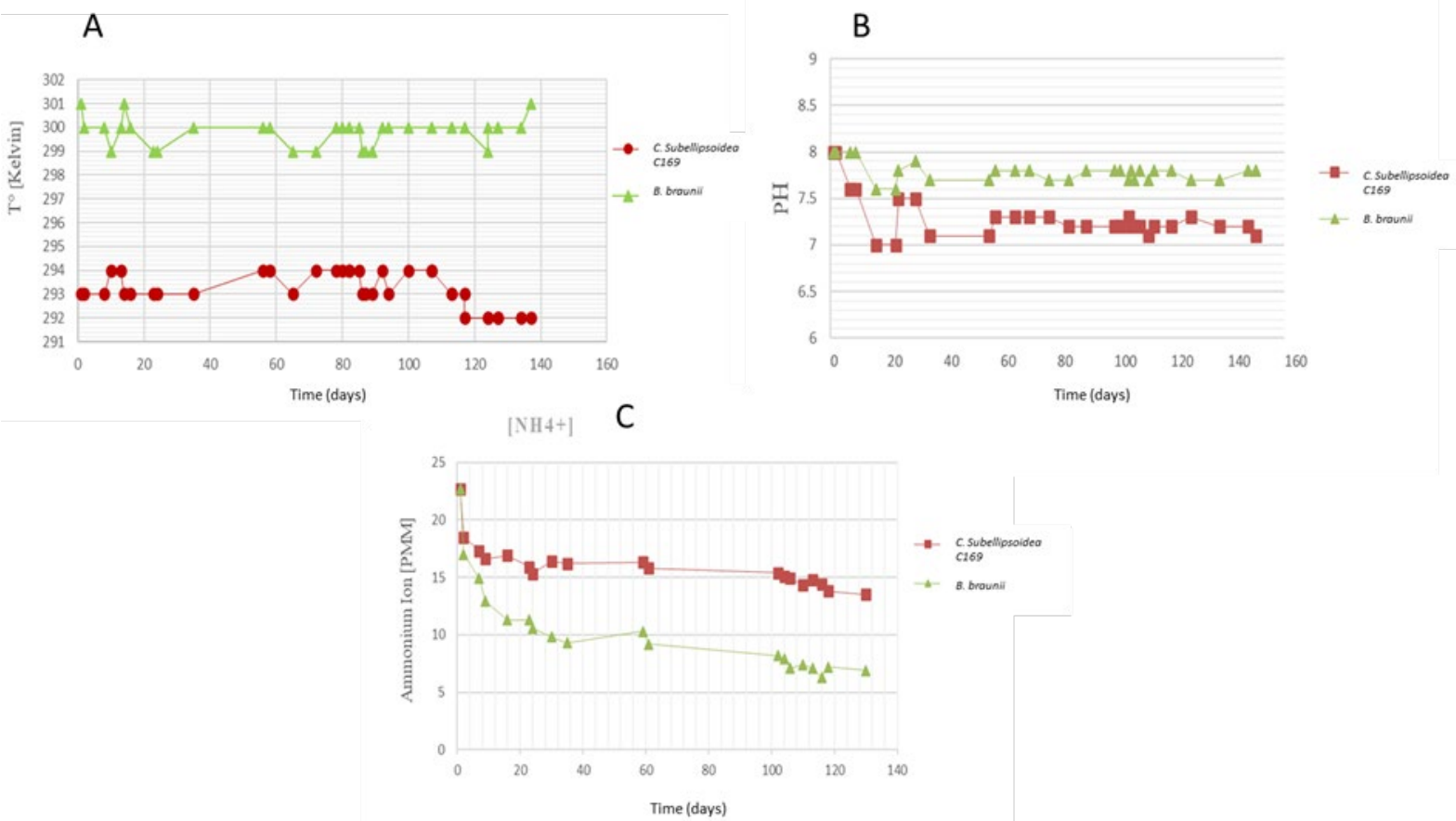

Fig. 3. (A) Temperature, (B) $\mathrm{pH}$ and (C) Consumption of ammonium ion of $\mathrm{pH}$ of C. subellipsoidea $\mathrm{C} 169$ and B. braunii. 


\section{Consumption speed kinetic}

Using the first order chemical reaction rate model, where the concentration of [A] decays exponentially with time. The first order reaction with respect to reagent [A] is as follows [22]:

\section{[A] $\rightarrow$ Product}

Differential velocity equation:

$$
v=-\frac{d[A]}{d t}=K_{A}[A]
$$

Eq. 1

Where $\mathrm{K}$ is the specific velocity coefficient. To obtain the equation that allows us to know how the concentration of the amine ion varies with time, we must integrate Eq. 1.

separating the variables:

$$
-\frac{d[A]}{[A]}=K_{A} d t
$$

Integrating:

$$
\begin{gathered}
-\int_{[A]_{0}}^{[A]_{t}} \frac{d[A]}{[A]}=K_{A} \int_{0}^{t} d t \\
\left(\ln [A]_{t}-\ln [A]_{0}\right)=-K_{A} t
\end{gathered}
$$

Solving for $\ln [A]_{t}$ we have the equation of a line:

$$
\ln [A]_{t}=-K_{A} t+\ln [A]_{0}
$$

Where:

$$
\begin{gathered}
\ln [A]_{t}=y \\
-K_{A} t=m \\
t=x \\
\ln [A]_{0}=b
\end{gathered}
$$

Then, the concentration of the ammonium ion ([A]) decays exponentially with time. The representation of $\ln [A]$ opposite $t$ gives a line of slop $-K_{A}$ and ordered at the origin $\ln [A]_{0}$.

In Fig. 4, we can observe the linear regression obtained. 
A

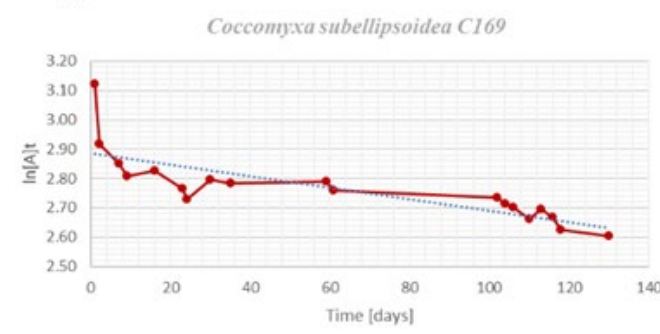

B

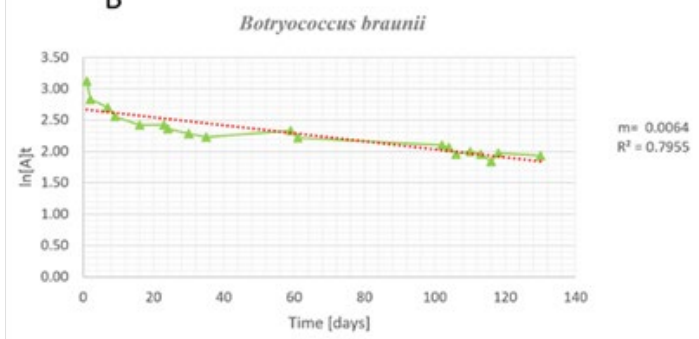

Fig. 4 (A) Velocity kinetics of ammonium ion consumption of C. subellipsoidea C169 and (B) Velocity kinetics of ammonium ion consumption of B. braunii.

To monitor cell growth activity in cultures, OD measurements were made. Follow-up of the cultures every $72 \mathrm{~h}$ showed a progressive increase in the absorbance values, showing cell growth. The culture of Coccomyxa subellipsoidea C169 beginning with a slightly low density of $0.02 \mathrm{~g} / \mathrm{L}$ against $0.34 \mathrm{~g} / \mathrm{L}$ of Botryococcus braunii in the first 9 days. Both crops grew upwards until the time of harvest. Fig. 5 shows the behavior of the kinetics of cell growth of both microalgae, a slow adaptation and growth phase can be observed, far from the stationary phase. The behavior of the Botryococcus braunii cell growth curve showed a progressive increase on Coccomyxa subellipsoidea C169. The final concentration values after 145 days were $2.85 \mathrm{~g} / \mathrm{L}$ and $2.53 \mathrm{~g} / \mathrm{L}$ respectively. These densities could perhaps be higher if the crops were kept exposed to sunlight with a higher light intensity.

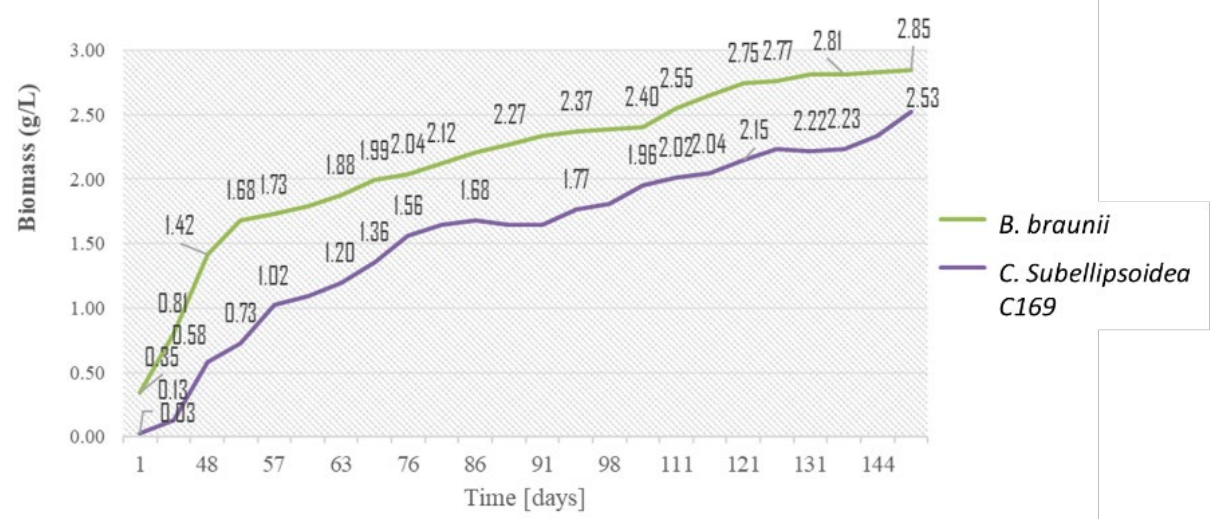

Fig. 5. Biomass production of B. braunii and C. subellipsoidea C169.

\section{Direct transesterification}

The direct transesterification at $358 \mathrm{~K}, 180 \mathrm{~min}$, allowed to achieve a good content of FAME, as shown by the analysis by gas chromatography (Fig.7). The biodiesel yields were over $100 \%$; for $B$. braunii was $89 \%$, while for $C$. subellipsoidea it was $88 \%$, this result was obtained with the equation described by [12]. Has been reported that these values are obtained when processing the well-dried biomass, since when the humidity increases the yield drops considerably, and because perhaps other molecules such as phospholipids, or accumulation of lipids on the cell surface, are also transformed into biodiesel $[10,12,21,24]$. 


\section{Biodiesel Characterization}

The specifications that biodiesel must meet are specified in the American Society for Testing and materials (ASTM) D6751 and EN 14214 in Europe, many of these specifications are related to fuel quality, however the integrity of the reaction is also considered. of transesterification, the storage conditions, and the composition of fatty acids, that is why the characterization of the biodiesel obtained is of great relevance.

\section{Fourier transform infrared spectroscopy (FT-IR)}

Biodiesel absorbs in the region of 2,750 cm-1 $-3,000 \mathrm{~cm}-1$ corresponding to the vibration modes of $\mathrm{CH} 2$ and $-\mathrm{CH} 3$. As the triglycerides present in the oil are converted to methyl esters when the reagent is methanol, the - $\mathrm{CH} 3$ groups increase in biodiesel composed mainly of fatty acid alkyl esters and therefore the intensity of the peak by $\sim 2924 \mathrm{~cm}-1$ also increases. On the other hand, the peaks between 1,170 cm-1 and 1,183 $\mathrm{cm}-1$ are assigned to the asymmetric vibration band of the $\mathrm{O}-\mathrm{C}-\mathrm{C}$ bonds [23]. These bonds are present in triglycerides, which tend to decrease when $\mathrm{C}-\mathrm{C}$ bonds are broken, resulting in three methyl esters for each triglyceride, a product that has lost the O-C-C groups. Only in case an alcohol with a higher number of carbon atoms is used, the number of these groups is conserved. Fig. 6 (A) and (B) show the spectra of the IR spectroscopy analysis of biodiesel obtained from microalgae.

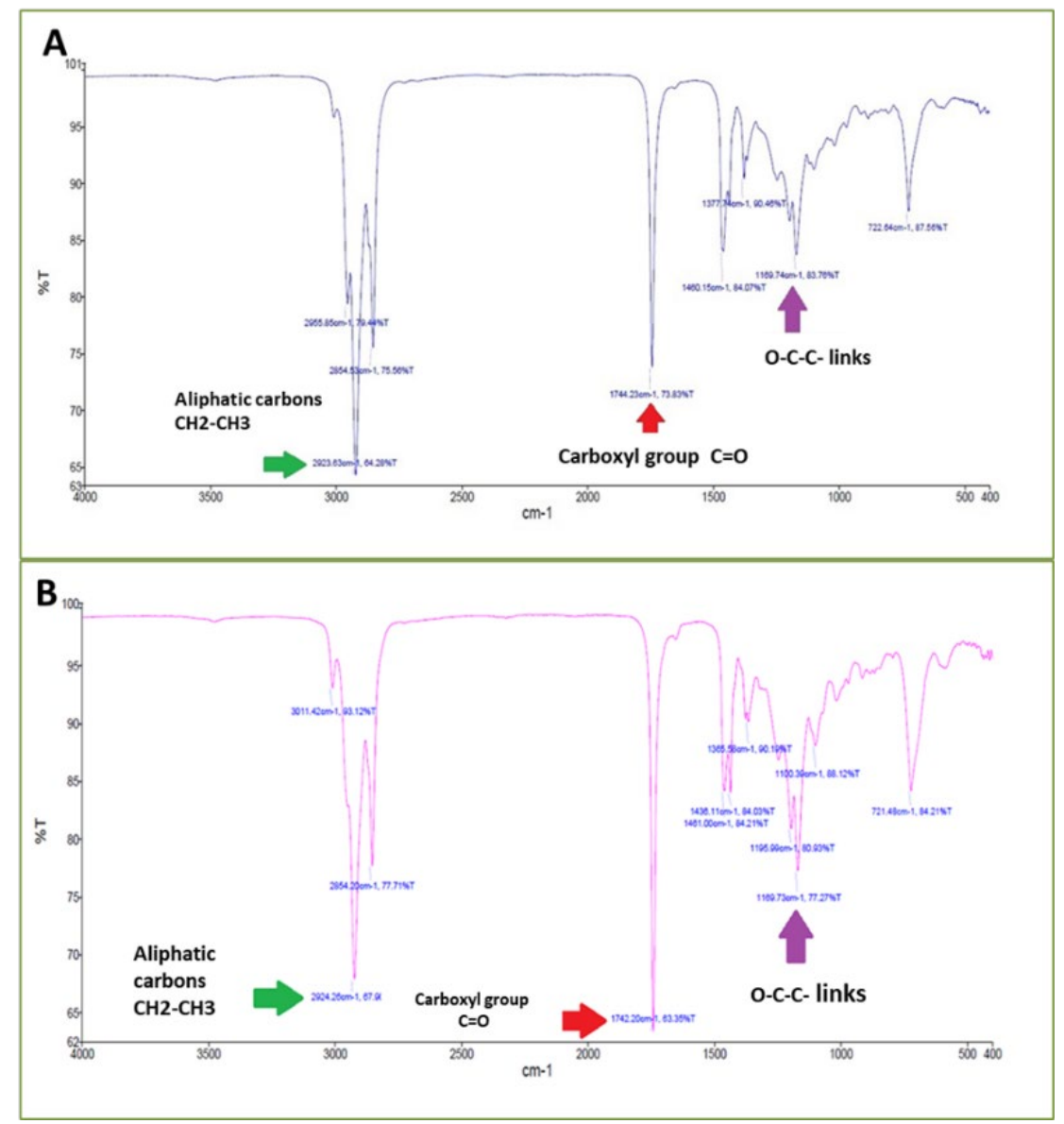

Fig. 6 (A) Spectrum (FT-IR) of biodiesel obtained from Botryococcus braunii and (B) Spectrum (FT-IR) of biodiesel obtained from Coccomyxa subellipsoidea C 169. 


\section{GC-linked mass spectrometry (GC-MS)}

For Botryococus braunii 9 fatty acids were identified and 10 for Coccomyxa subellipsoidea C 169. Some of these FAMEs were found in both species, but in different concentrations. The result can be seen in the chromatograms of the fatty acid profile, Fig. 7 (A) and (B).

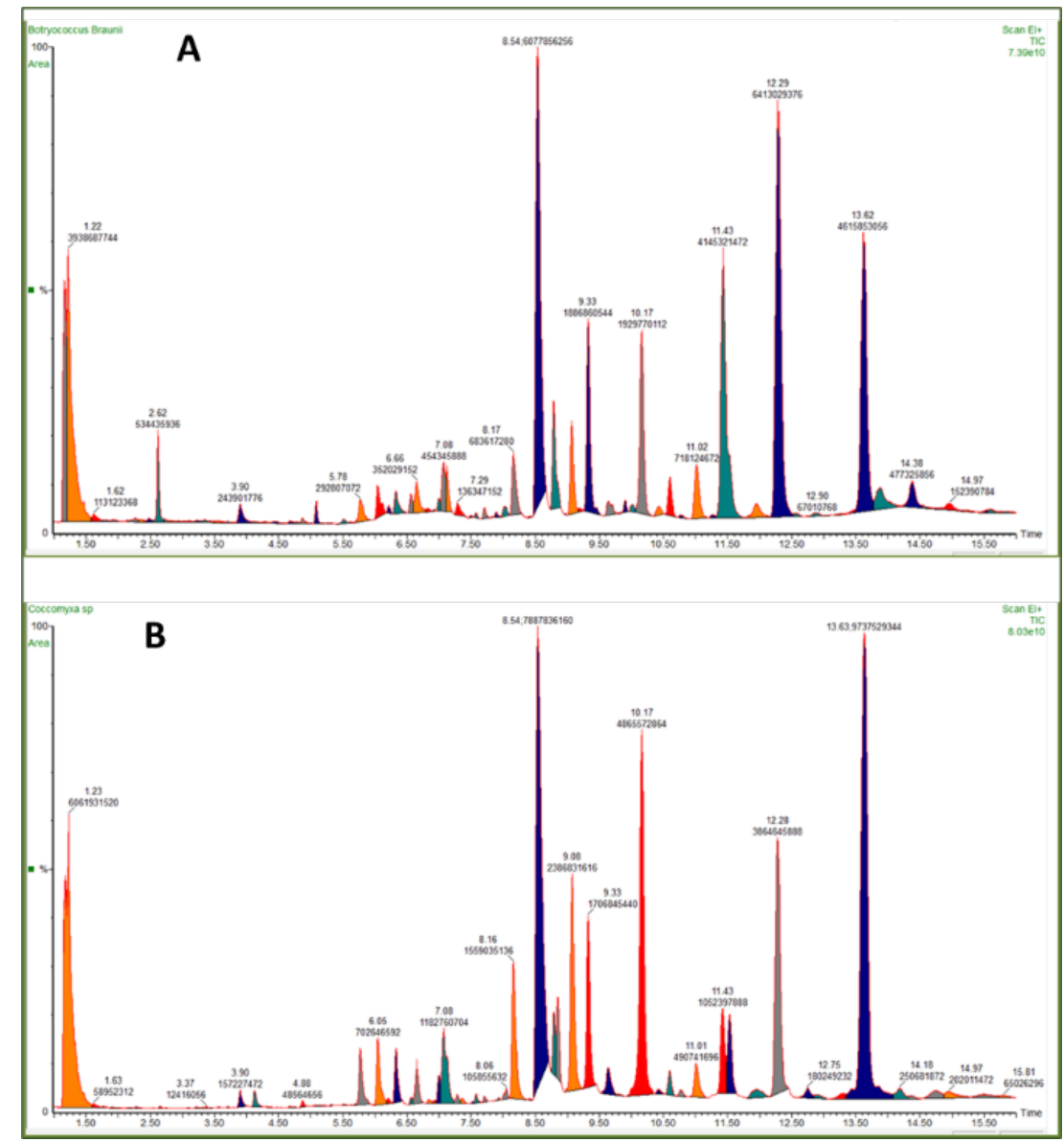

Fig. 7. (A) FAME chromatogram of Botryococcua braunii and (B) FAME chromatogram of Coccomyxa subellipsoidea $\mathrm{C} 169$.

The content and lipid composition of algae vary according to species, geographic location, season, temperature, salinity, light intensity, or a combination of these factors. In general, algae contain around 1-3\% of the dry weight in lipids, with most of all algae classes being glycolipids, followed by neutral lipids and phospholipids [10,24].

Tables 1 and 2 show the fatty acids that were determined for both studied microalgae and correspond to the peaks obtained in the chromatograms presented in Fig. 7. 
Table 1. Identification by GC-MS of the content of fatty acids of methyl ester (FAME) corresponding to Botryococcus braunii.

ID: Identification, SAFA: Saturated fatty acid, MUFA: Monounsaturated fatty acid,

\begin{tabular}{|c|c|c|c|c|c|c|}
\hline ID & $\begin{array}{l}\text { Holdin } \\
\text { g time } \\
\text { (min) }\end{array}$ & $\begin{array}{c}\text { Fatty } \\
\text { Acid } \\
\text { Family }\end{array}$ & Comon Name & $\begin{array}{c}\text { Fatty acid } \\
\text { (methyl ester) }\end{array}$ & $\begin{array}{c}\text { Abbreviated } \\
\text { representation }\end{array}$ & $\begin{array}{c}\text { Abundance } \\
\text { (area units / } 40 \\
\mu \mathrm{l})\end{array}$ \\
\hline 1 & 6.661 & & Myristic acid & $\begin{array}{c}\text { Tetradecanoic } \\
\text { acid }\end{array}$ & $\mathrm{C} 14: 0$ & 0.0124 \\
\hline 2 & 8.541 & & Palmitic acid & hexadecanoic acid & $\mathrm{C} 16: 0$ & 0.2438 \\
\hline 3 & 8.831 & $\omega-7$ & Palmitoleic acid & $\begin{array}{c}\text { cis-9 } \\
\text { hexadecenoic }\end{array}$ & C16:1 & 0.0356 \\
\hline 4 & 9.352 & $\omega-6$ & Linoleic acid & 6-9-octadecaenoic & $\mathrm{C} 18: 2$ & 0.2925 \\
\hline 5 & 10.182 & & $\begin{array}{c}\text { Hexadecatrienoic } \\
\text { acid }\end{array}$ & - & $\mathrm{C} 16: 3$ & 0.0680 \\
\hline 6 & 10.622 & $\omega-6$ & Arachidonic acid & $\begin{array}{c}\text { 8-11-14-17 } \\
\text { eicosatetraenoic }\end{array}$ & C20:4 & 0.0136 \\
\hline 7 & 11.022 & & Stearic acid & Methyl stearate & $\mathrm{C} 18: 0$ & 0.0253 \\
\hline 8 & 11.433 & $\omega-9$ & Oleic acid & $\begin{array}{c}\text { cis-9- } \\
\text { octadecaenoic }\end{array}$ & C18:1 & 0.1461 \\
\hline \multirow[t]{4}{*}{9} & 13.613 & $\omega-3$ & Linolenic acid & $\begin{array}{c}\text { cis-9,12,15- } \\
\text { octadecatrienoic } \\
(\text { ALA) }\end{array}$ & C18:3 & 0.1627 \\
\hline & & & & & $\begin{array}{c}\text { Total, area } \\
\text { SAFA }\end{array}$ & $\begin{array}{c}0.2818= \\
28.17 \%\end{array}$ \\
\hline & & & & & $\begin{array}{c}\text { Total, area } \\
\text { MUFA }\end{array}$ & $0.1817=18.16 \%$ \\
\hline & & & & & $\begin{array}{c}\text { Total, area } \\
\text { PUFA }\end{array}$ & $\begin{array}{c}0.5368= \\
56.66 \%\end{array}$ \\
\hline
\end{tabular}

PUFA: Polyunsaturated fatty acid.

Table 2. Identification by GC-MS of the content of fatty acids of methyl ester (FAME) corresponding to Coccomyxa subellipsoidea $\mathrm{C} 169$.

\begin{tabular}{|c|c|c|c|c|c|c|}
\hline ID & $\begin{array}{c}\text { Holding } \\
\text { time } \\
\text { (min) }\end{array}$ & $\begin{array}{c}\text { Fatty } \\
\text { Acid } \\
\text { Family }\end{array}$ & $\begin{array}{l}\text { Comon } \\
\text { Name }\end{array}$ & $\begin{array}{c}\text { Fatty acid } \\
\text { (methyl ester) }\end{array}$ & $\begin{array}{c}\text { Abbreviated } \\
\text { representation }\end{array}$ & $\begin{array}{c}\text { Abundance } \\
\text { (area units / } \\
\quad 40 \mu \mathrm{l})\end{array}$ \\
\hline 1 & 4.875 & & Lauric acid & Dodecanoic acid & $\mathrm{C} 12: 0$ & 0.0015 \\
\hline 2 & 6.651 & & myristic acid & $\begin{array}{c}\text { Ácido } \\
\text { tretradecanoico }\end{array}$ & $\mathrm{C} 14: 0$ & 0.0121 \\
\hline 3 & 8.551 & & Palmitic acid & Hexadecanoic acid & $\mathrm{C} 16: 0$ & 0.2497 \\
\hline 4 & 8.857 & $\omega-9$ & $\begin{array}{c}\text { Palmitoleic } \\
\text { acid }\end{array}$ & cis 9-hexadecenoic & C16:1 & 0.0032 \\
\hline 5 & 9.087 & $\omega-7$ & $\begin{array}{c}\text { ácido } \\
\text { palmitoleíco }\end{array}$ & cis 7 - hexadecenoic & C16:1 & 0.0719 \\
\hline 6 & 9.332 & $\omega-6$ & Linoleic acid & $\begin{array}{c}\text { cis 9-12- } \\
\text { octadecadienoic }\end{array}$ & C18:2 & 0.1678 \\
\hline 7 & 10.167 & $\omega-3$ & Linoleic acid & $\begin{array}{c}\text { cis-9-12-15- } \\
\text { octadecadienoic }\end{array}$ & $\mathrm{C} 18: 3$ & 0.1497 \\
\hline
\end{tabular}




\begin{tabular}{|c|c|c|c|c|c|c|}
\hline $\mathbf{8}$ & 10.602 & $\omega-6$ & $\begin{array}{c}\text { Arachidonic } \\
\text { acid }\end{array}$ & $\begin{array}{c}8-11-14-17 \\
\text { eicosatetraenoic }\end{array}$ & C20:4 & 0.0075 \\
\hline $\mathbf{9}$ & 11.017 & & stearic acid & - & C18:0 & 0.0148 \\
\hline $\mathbf{1 0}$ & 11.438 & $\omega-9$ & Oleic acid & $\begin{array}{c}\text { cis-9- } \\
\text { eicosatetraenoic }\end{array}$ & C18:1 & 0.0317 \\
\hline & & & & & $\begin{array}{c}\text { Total, area } \\
\text { SAFA }\end{array}$ & $\begin{array}{c}0.2781= \\
39.17 \%\end{array}$ \\
\hline & & & & & $\begin{array}{c}\text { Total, area } \\
\text { MUFA }\end{array}$ & $\begin{array}{c}0.1068= \\
15.04 \%\end{array}$ \\
\hline & & & & & $\begin{array}{c}\text { Total, area } \\
\text { PUFA }\end{array}$ & $\begin{array}{c}0.325= \\
45.78 \%\end{array}$ \\
\hline
\end{tabular}

ID: Identification, SAFA: Saturated fatty acid, MUFA: Monounsaturated fatty acid, PUFA: Polyunsaturated fatty acid.

The major compounds determined in this work, were hexadecanoic acids (palmitic acid); 6,9octadecaenoic (Linoleic Acid) $\omega-6$ and its derivative $\omega-3$; cis-9,12,15-octadecatrienoic (linolenic acid) $\omega$-3, cis7- hexadecenoic (palmitoleic acid) $\omega-7$ and cis-9-octadecaenoic (oleic acid) $\omega-9$, these 5 fatty acids represent approximately the $90 \%$ and $85 \%$ of the total FAME area.

Other fatty acids present in a lower concentration, but also important, were tetradecanoic acids (myristic acid) and 8,11,14,17 eicosatetraenoic (arachidonic acid (ARA) $\omega-6$.

These results indicate that Botryococcus braunii and Coccomyxa subellipsoidea C169. are microalgae rich mainly in polyunsaturated fatty acids (PUFA) and saturated (SAFA).

The Fig. 8 show the mass spectrum and structure of each of the 5 main FAME identified from the fatty acids produced by Botryococcus braunii and Coccomyxa subellipsoidea C 169.

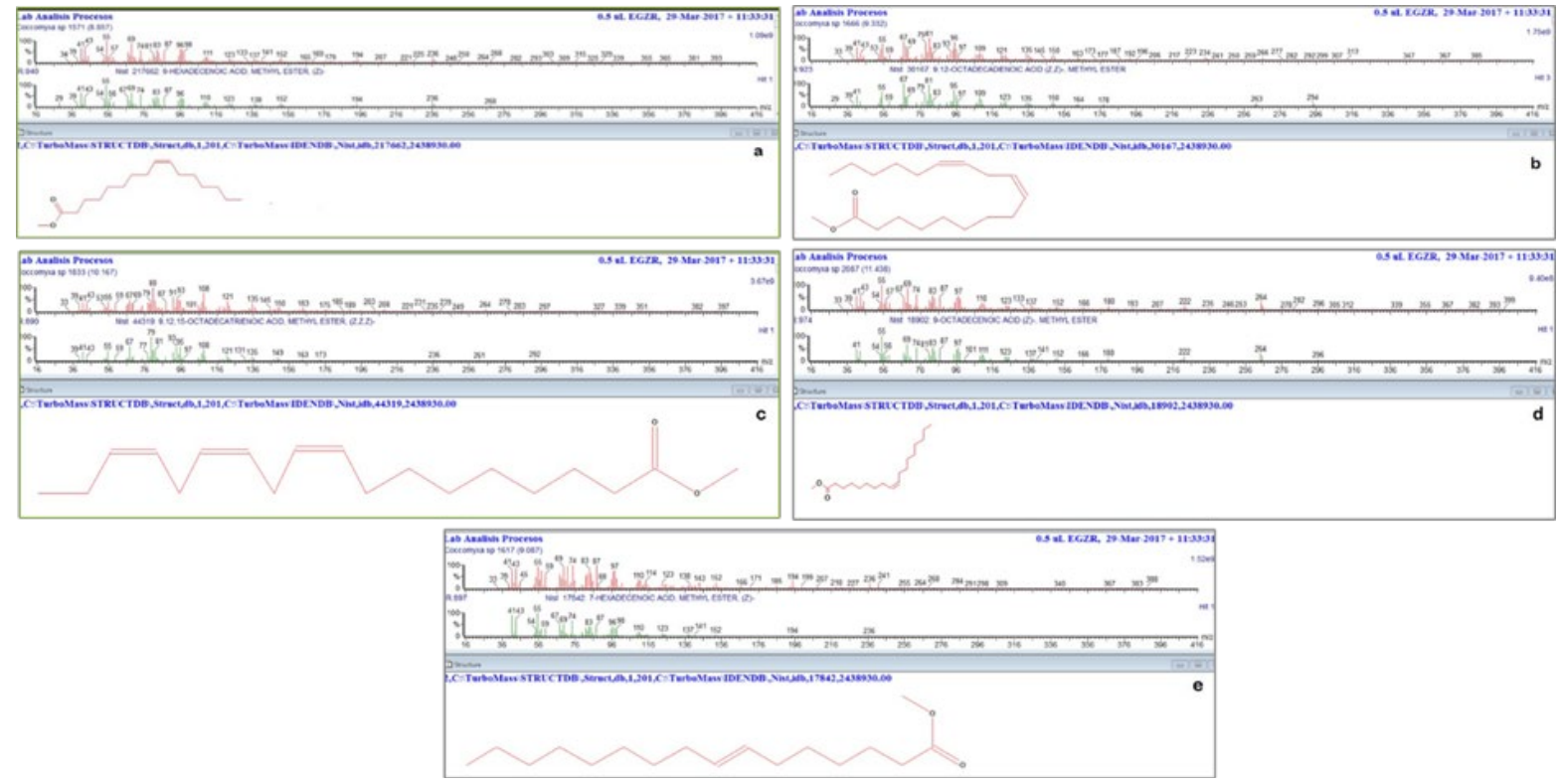

Fig. 8. Chromatography and structure of (a) Palmitic acid C16:0; (b) C18: $2 \omega-6$ linoleic acid; (c) C18: $3 \omega-3$ linolenic acid; (d) C18: $1 \omega-9$ oleic acid and (e) C16:1 $\omega$-7 palmitoleic acid.

These methyl esters were produced during the direct transesterification reaction carried out in this work, moreover hydrocarbons may be also suited for different industrial applications like food industry, among others. 
Recent studies show that microalgae are the best and ever green source for biodiesel production as microalgae has many advantages over other conventional sources $[2,3,4,10,25,26]$.

\section{Conclusion}

As we know, the production of biofuels is not cheap, and is on the rise, so the use of microalgae grown in wastewater turned out to be a good alternative to cheapen the costs, therefore, both species of microalgae ( $B$. braunii and C. subellipsoidea C169) can be considered a good option to produce hydrocarbons of commercial interest, since the yield of biodiesel is close to $100 \%$. Moreover, a greater understanding of their metabolic processes may allow the genetic engineering of algal strains with increased capacity to convert their biomass into useful biofuel precursors.

Furthermore, use wastewater as a nutritive medium, ensure the possibility of obtaining good growth and cell productivity in a nutritive medium that is cheaper than the conventional one.

Additionally, the process to obtain biofuels consumes high energy in the different stages: during the extraction of biomass, the harvest, during cell disruption, drying of the biomass, conversion to biodiesel and the separation of derivative products such as glycerin, among others; that is why the application of direct transesterification is a good alternative that reduces critical steps for obtaining biodiesel.

We considered that the key parameters for direct transesterification are the moisture content of the biomass, the amount of solvent, sulfuric acid, and the final yield of FAME. We observed that the heating time in the direct transesterification reaction greatly influenced the concentration of FAMEs. The time of $180 \mathrm{~min}$. and $85^{\circ} \mathrm{C}$, it was enough to get a conversion of almost all fatty acids present in the sample.

C. subellipsoidea C-169 synthesized less than $50 \%$ of PUFAs while from B. braunii $53.66 \%$ was obtained. C. subellipsoidea C-169 metabolized $11 \%$ more SAFAs compared to B. braunii, so that $B$. braunii and $C$. subellipsoidea $\mathrm{C}-169$ grown in wastewater and optimal conditions in the laboratory are microalgae rich in polyunsaturated fatty acids (PUFA) and saturated (SAFA) with high added value ( $\omega-3$ and $\omega-6)$ and the biodiesel obtained is of high quality since it complies with the European Biodiesel Standard EN14214 which specifies a limit of 12 and $1 \%$ for unsaturation levels (C18:3) and polyunsaturated respectively.

Finally, both microalgae grew successfully in the wastewater, so this also reduced costs, which is remarkable; In addition, oil yield is higher in microalgae compared to oilseed plants.

All authors have read and agree to the manuscript and there is no conflict of interest between them, any additional information or data may be requested to the corresponding author (BECS).

\section{Acknowledgements}

To the program for the Professional Development of Full Professors, for the superior level (PRODEPSEP), for the financing granted to BECS, Ph D. for receiving the distinction of Desirable Profile (2017-2018) UAM economy number 35141. To Ing. Aleph Sánchez Ayala, for supporting us in the sonication of biomass in the Laboratory of Processes in Aqueous Systems of the UAM-Azcapotzalco, and Margarita González Brambila, $\mathrm{Ph}$ D. Director of the Department of Energy (2014-2017) UAM-Azcapotzalco, for the facilities to carry out this research.

\section{References}

1. Castillo, O.; Torres-Badajoz, S.; Núñez-Colín, C.; Peña-Caballero, V.; Herrera Méndez, C.; Rodríguez-Núñez, J. Hidrobiológica. 2017, 27, 337-352. DOI: 10.24275/uam/izt/dcbi/hidro/2017v27n3/Rodriguez 
2. Yousuf, A.; Rahman, M.; Khan, M. R.; Islam, M.A.; Wahid, Z.A.; Pirozzi, D. Biotechnol. Lett. 2016, 39, 13-23. DOI: 10.1007/s10529-016-2217-x

3. Harish, M.; Krishna, S.; Murthy, T. P.; Mathew, B.; Ananda, S. IJERA. 2013, 3, 902-913.

4. Chisti, Y. Biotechnol. Adv. 2007, 25, 294-306. DOI: https://doi.org/10.1016/j.biotechadv.2007.02.001

5. http://dx.doi.org/10.1787/agr outlook-2017-es, accessed in March 2021.

6. Smith, L.L.; Fox, J.M.; Granvil, D.R.; McVey, J.P. Intensive larviculture techniques. In: CRC Handbook of mariculture. Volume 1. Crustacean Aquaculture. $2^{\circ} \mathrm{Ed}$. CRC Press, Inc., Boca Raton, Florida, USA, 1993, 105-109.

7. https://doi.org/10.1787/4919645f-en, accessed in March 2021.

8. Knothe, G. Energy Fuels. 2008, 22, 1358-1364. DOI: 10.1021/ef700639e

9. Liam, B.; Philip, O. Renew. Sustain. Energy Rev. 2010, 14, 557-577. DOI: https://doi.org/10.1016/j.rser.2009.10.009

10. Suzuki, R.; Ito, N.; Uno, Y.; Nishii, I.; Kagiwada, S.; Okada, S.; Noguchi, T. PLOS. 2013, 8, e81626. DOI: https://doi.org/10.1371/journal.pone.0081626

11. Park, J.Y.; Park, M. S.; Lee, Y.C.; Yang, J.W. Bioresour. Technol. 2015, 184, 267-275. DOI: http://dx.doi.org/10.1016/j.biortech.2014.10.089

12. Cao, H.; Zhang, Z.; Wu, X.; Miao, X. Biomed. Res. Int. 2013, 2013, 1-6. DOI: https://doi.org/10.1155/2013/930686

13. Mondala, A.; Liang, K.; Toghiani, H.; Hernandez, R.; French, T. Bioresour. Technol. 2009, 100, 12031210. DOI: 100(3):1203-10. DOI: 10.1016/j.biortech.2008.08.020.

14. Qi, J.; Zhu, F.; Wei, X.; Zhao, L.; Xiong, Y.; Wu, X.; Yan, F. Waste Manage. 2016, 49, 212-220. DOI: https://doi.org/10.1016/j.wasman.2016.01.029

15. Tatli, M.; Chun, H.; Camp, H.; Li, J.; Cicerone, T.; Shih, W.; Laane, J.; Devarenne, T. J. Mol. Struct. 2017, 1147, 427-437. DOI: http://dx.doi.org/10.1016/j.molstruc.2017.06.126

16. Metzger, P.; Largeau, C. Chemicals of Botryococcus braunii. Taylor \& Francis, London, 1999, 205260.

17. Holm-Hansen, O. Phycologia. 1964, 4, 43-51. DOI: https://doi.org/10.2216/i0031-8884-4-1-43.1

18. Higashiyama, T.; Noutoshi, Y.; Fujie, M.; Yamada, T. EMBO J. 1997, 16, 3715-3723. DOI: 10.1093/emboj/16.12.3715

19. Halim, R.; Harun, R.; Danquah, M.; Webley, P. Appl. Energy. 2012, 91, 116-121. DOI: 10.1016/j.apenergy.2011.08.048

20. López-Elías, J.: Huerta-Aldaz, N.; Estrada-Durán, G.; Celis-Salgado, M.; De la Re-Vega, E.; QuinteroArredondo, N.; Estrada-Quintero, J.; Niebla-Larreta, J.; Miramontes-Higuera, N.; García-Quiroz, K.; Rodríguez-Niebla, J.; Carvajal-Sánchez, I.; Velasco-Rameños, J. Biotecnia. 2005, 3, 10-15. DOI: https://doi.org/10.18633/bt.v11i1.48

21. Msanne, J.; Xu, D.; Reddy, A.; Casas, J.; Awada, T.; Cahoon, E.; Cerutti, H. Phytochemistry. 2012, 75, 50-59. DOI: 10.1016/j.phytochem.2011.12.007

22. Beyer, H.; Walter, W. Organic Chemistry, a Comprehensive Degree Text and Sourcebook. 1999, 1037.

23. Silverstein, R.; Bassler, G.; Morrill, T. Spectrometric identification of organic compounds. 5th ed. New York: John Wiley, 1991, 430.

24. Antonopoulou, S.; Karantonis, H.C.; Nomikos, T.; Oikonomou, A.; Fragopoulou, E.; Pantazidou, A. Biochem. Mol. Biol. 2005, 142, 269-282. DOI: 10.1016/j.cbpc.2005.07.007

25. Karmakar, A.; Karmakar, S.; Mukherjee, S. Bioresour. Technol. 2010, 101, 7201-7210. DOI: https://doi.org/10.1016/j.biortech.2010.04.079

26. Parag, S.; Sayali, J.; Joshipurac, H. Procedia Eng. 2013, 51, 395-402. DOI: https://doi.org/10.1016/j.proeng.2013.01.055 